\title{
THE OPTIMIZATION OF PLACING ELECTRONIC COMPONENTS BY A MODIFIED ALTERNATING-VARIABLE DESCENT METHOD
}

DOI: $10.36724 / 2072-8735-202|-| 5-3-59-63$

Manuscript received 02 December 2020; Accepted 26 January 2021

Tigran R. Harutyunyan, JSC " MIC "NPO mashinostroeniya", Moscow, Russia, tigran_201094@mail.ru

Keywords: electrical circuit, placement constraints, topological parameters, metric parameters, switching field, optimization criteria and methods

\begin{abstract}
The problem of optimal placement of elements of electrical and electronic circuits is considered. The minimum weighted connection length is selected as the criterion. A computational method is proposed that is a modification of the coordinate descent method and one of the variants of the General approach based on pair permutations. The scheme is defined by the connection matrix. We consider a fixed set of element positions and a distance matrix based on an orthogonal metric. This problem is a variant of the General mathematical model, called the quadratic assignment problem. Geometric restriction of the problem - no more than one element can be placed in one cell. It is stated that approaches based on paired and similar permutations are economical, and the method of the penalty function leads to" ditching " and is ineffective. A modified coordinate descent method is described, which is a variant of the pair permutation method, in which pairs are selected based on the coordinate descent method. In the proposed version of the coordinate descent method, two coordinates are changed simultaneously at one stage of calculations (and not one, as in the usual optimization method). one of the coordinates is used for the usual trial step, and the other is used for correction, returning to the acceptable area. Next, the value of the target function is calculated at the found point and compared with the previously reached value. If the value has improved, the found point becomes the new starting point. Otherwise, a step is made on a different coordinate with simultaneous correction of the vector of item position numbers (return to the allowed area). The experience of using the modified method in solving the problem of placing EVA elements has shown its significant advantages in comparison with other known methods, for example, the genetic algorithm, as well as the method of penalty functions. An example of calculations using the proposed method is considered. The connection matrix was set analytically. First, the initial approximation was searched by the Monte Carlo method ( 10,000 iterations), after which the local optimum was calculated using a modified method of coordinate descent in the permutation space without repetitions (a limit of 100 iterations was set). The initial value of the coordinate step is equal to the size of the permutation, then at each iteration it was reduced by $I$ to the minimum possible value of $I$. The advantage of this method is that there is no penalty function. The search is performed automatically in the permutation space without repetitions. Computational experiments have shown high computational qualities of the proposed method.
\end{abstract}

Information about author:

Tigran R. Harutyunyan, programmer of JSC "MIC "NPO mashinostroeniya", Moscow, Russia

Для цитирования:

Арутюнян Т.Р. Оптимизация размещения равногабаритных элементов РЭА модифицированным методом покоординатного спуска // T-Comm: Телекоммуникации и транспорт. 202।. Том 15. №3. С. 59-63.

For citation:

Harutyunyan T.R. (202I) The optimization of placing electronic components by a modified alternating-variable descent method. T-Comm, vol. 15, no.3, pp. 59-63. (in Russian) 


\section{Introduction}

The problem of optimal placement of elements of electrical and electronic circuits and tracing their connections is one of the most relevant in the design of radio equipment. Various criteria and restrictions, as well as mathematical models and methods are used to solve this problem [1-10]. As a result of the calculation, the coordinates of the location of individual circuit elements on the switching field and the topological characteristics of the connections of their terminals are found.

Criteria and restrictions are divided into two groups: metric parameters (dimensions of elements and distances between them, dimensions of the switching field, distances between the terminals of elements, permissible lengths of connections, etc.), topological parameters (the number of spatial intersections of connections, the number of interlayer transitions, the proximity of fuel elements to each other or elements and connections that are incompatible in the electromagnetic relation).

The problem is formulated as follows: a set of structural elements connected to each other in accordance with the basic electrical diagram of the node is given. It is required to place elements on a flat switching field (CP) in such a way that some functional reaches an extreme value. The CP options can be: a panel with wired connections, a printed circuit Board, a microassembly substrate, and an ENCORE crystal.

For structurally similar elements, the positions for their installation on the gearbox are fixed, located in the nodes of a rectangular grid, and can be described by the following system of parameters: Introduction

The problem of optimal placement of elements of electrical and electronic circuits and tracing their connections is one of the most relevant in the design of radio equipment. Various criteria and restrictions, as well as mathematical models and methods are used to solve this problem [1 - 10]. As a result of the calculation, the coordinates of the location of individual circuit elements on the switching field and the topological characteristics of the connections of their terminals are found.

Criteria and restrictions are divided into two groups: metric parameters (dimensions of elements and distances between them, dimensions of the switching field, distances between the terminals of elements, permissible lengths of connections, etc.), topological parameters (the number of spatial intersections of connections, the number of interlayer transitions, the proximity of fuel elements to each other or elements and connections that are incompatible in the electromagnetic relation).

The problem is formulated as follows: a set of structural elements connected to each other in accordance with the basic electrical diagram of the node is given. It is required to place elements on a flat switching field (CP) in such a way that some functional reaches an extreme value. The CP options can be: a panel with wired connections, a printed circuit Board, a microassembly substrate, and an ENCORE crystal.

For structurally similar elements, the positions for their installation on the gearbox are fixed, located in the nodes of a rectangular grid, and can be described by the following system of parameters: $n_{x}, n_{y}, h_{x}, h_{y}$, where $n_{x}$ - number of positions in the horizontal row; $n_{y}$ - number of positions in the vertical row; $h_{x}$ - the horizontal spacing between positions; $h_{y}$ - vertical step between positions.
Possible design features of the gearbox related to the location of contacts of elements and external terminals of the node can be determined by an additional set of parameters: the coordinates of the contact pads relative to the centers of the position $\left(x_{b}, y_{b}\right)$ etc.

When designing printed circuit boards with different-sized hinged elements, hybrid IC substrates, as well as solid-state IC and BIS topologies with a single switching layer, the positions for placing elements are not fixed in advance and are finally determined after tracing the connections. A characteristic feature of placement problems in these structures is the need to take into account the different dimensions of individual elements, the requirements for minimizing the total area occupied by the scheme, and restrictions on the number of internal intersections.

In most cases, the criterion is the minimum weighted length (MSWD) of connections, which integrally takes into account the numerous requirements for the location of elements and the routes of their connections [5-10]. This is due to a number of factors:

reducing the connection lengths improves the electrical parameters of the circuit;

the shorter the total length of connections, the easier it is to implement them in the tracing process, on average;

reducing the total length of connections reduces the complexity of manufacturing wiring diagrams, especially wiring diagrams;

this criterion is relatively simple from a mathematical point of view and allows you to indirectly take into account other parameters of the schemes by assigning weight ratings to individual compounds.

\section{A description of the method}

Let the elements be given $e_{1}, \ldots, e_{n}$ and for each pair of elements, weight coefficients are set $r_{i j}(i, j=1, \ldots, n)$ defining the "degree of connection" of elements with each other. Thus, we assume that the scheme is given by a matrix of connections

$$
R=\left\{r_{i j}\right\}_{i, j=1, \ldots, n} .
$$

Let there be some fixed set of positions for placing elements $p_{1}, \ldots, p_{m}(m \geq n)$. In the future, we will assume that $m=n$.

If $m>n$ you can enter $(m-n)$ dummy elements that do not have connections to other elements $r_{i j}=0,(i=n+1, \ldots, m ; j=1, \ldots, m)$.

Determine the distance $d_{i j}(i, j=1, \ldots, n)$ between pairs of positions.

To do this, we will use additional information. Let's assume that the positions for placing elements are fixed on the switching field. You can set a distance matrix for them

$$
D=\left\{d_{i j}\right\}_{i, j=1, \ldots, n},
$$

in which the element $d_{i j}(i, j=1, \ldots, n)$ is equal to the distance between the centers of the positions $p_{i}, p_{j}$. The matrix $D=\left\{d_{i j}\right\}_{i, j=1, \ldots, n}$ is symmetric, with a zero main diagonal $d_{i i}=0(i=1, \ldots, n)$. 
To calculate the elements of the matrix $D$, an orthogonal metric is used, and the distance between adjacent vertical and horizontal positions is equal to 1 .

An arbitrary placement of elements in positions is a permutation $p=\left(p_{1}, \ldots, p_{n}\right)$, where $p_{i}$ it sets the number of the position assigned to the $i$-th element. Thus, there are a total $n$ ! of different options for placing elements.

Attempts to find the optimal option by full search are unsuccessful even for small values of $n$ : 9 ! $=362880,16$ ! = $20922789888000=10^{13,32 \ldots} .25=15511210043330985984000000$ $=10^{25,19 \ldots}$.

Consider the problem of minimizing the total weighted length (MSWD) of connections under the following assumptions.

We consider connections to be conditionally derived from the geometric centers of elements. In addition, we assume that the centers of elements and positions coincide. As a rule, when solving the placement problem, it is necessary to take into account the pre-anchoring of some elements in positions and connecting elements to external outputs. By mapping an element to external outputs and fixing the location of some elements, we get a simplified representation of the switching field (Fig. 1).

Obviously, the length of the connections between the elements $e_{i}$ and $e_{j}$ is estimated by

$$
L_{i j}=r_{i j} d_{p(i) p(j)}(i, j=1, \ldots, n) \text {. }
$$

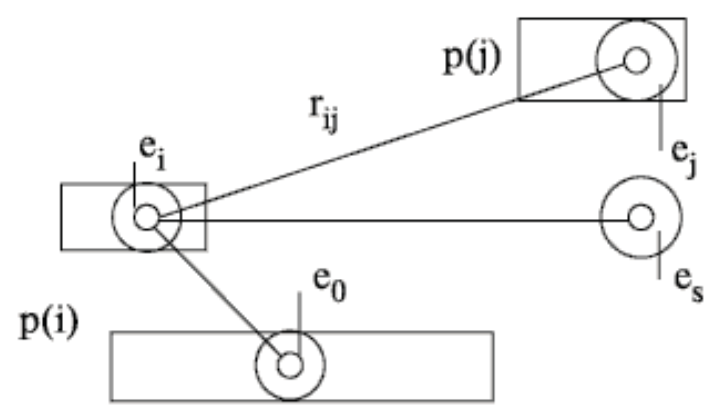

Figure 1. Representation of the switching field

$$
\begin{array}{cccc}
0 & 0 & 0 & 0 \\
1 & 2 & 3 & 4 \\
0 & 0 & 0 & 0 \\
5 & 6 & 7 & 8 \\
0 & 0 & 0 & 0 \\
9 & 10 & 11 & 12 \\
\hline
\end{array}
$$

Figure 2. Fixed set of 12 positions

Denote by $E_{S}$ the set of all fixed elements, including the element $e_{0}$; then the total weighted length of the element's $e_{i}$ connections with elements from $E_{S}$ is estimated by the formula:

$$
a_{i p(i)}=\sum_{s \in E_{s}} r_{i s} d_{p(i) s}(i=1, \ldots, n)
$$

where $d_{p(i) s}$ is the distance between the element $e_{i}$ in position $p_{i}$ and the element $e_{s}$.
Given the above and the symmetry of the matrices $R$ and $D$, we write the expression for the total weighted length of ports at arbitrary location:

$$
F(p)=\frac{1}{2} \sum_{i=1}^{n} \sum_{j=1}^{n} r_{i j} d_{p(i) p(j)}+\sum_{i=1}^{n} a_{i p(i)} .
$$

Thus, the problem of placing the criterion MSWD compounds consists in the minimization of functional (5) on the set of permutations of $P$ compounds:

$$
F(p)=\frac{1}{2} \sum_{i=1}^{n} \sum_{j=1}^{n} r_{i j}\left(\left|x_{i}-x_{j}\right|+\left|y_{i}-y_{j}\right|\right)+\sum_{i=1}^{n} \sum_{s \in E_{s}} r_{i s}\left(\left|x_{i}-x_{s}^{0}\right|+\left|y_{i}-y_{s}^{0}\right|\right)
$$

This task is a variant of a General mathematical model, called quadratic assignment.

Geometric constraint - no more than one element can be placed in a single cell, i.e.

$$
\begin{aligned}
& \min _{i, j=1, \ldots n} \max \left\{\frac{\left|x_{i}-x_{j}\right|}{h_{x}}, \frac{\left|y_{i}-y_{j}\right|}{h_{y}}\right\} \geq 1, \\
& \min _{i=1, \ldots n} \max \left\{\frac{\left|x_{i}-x_{s}^{0}\right|}{h_{x}}, \frac{\left|y_{i}-y_{s}^{0}\right|}{h_{y}}\right\} \geq 1, \\
& x_{i}=I_{i} h_{x}, y_{i}=J_{i} h_{y}, i=1, \ldots, n ; I_{i} \in\{1, \ldots, n\}, J_{i} \in\{1, \ldots, n\}
\end{aligned}
$$

\section{Modified coordinate descent method in the location problem}

We will solve the integer optimization problem with the objective function $F(x)$, where $x$ is the vector of the optimized placement parameters, namely, the permutation without repetition of the position numbers of $n$ elements. The coordinates of the cells for placing elements can be calculated through the position number. This approach is economical because geometric constraints are automatically taken into account. Experience shows that if the problem is solved in the usual way for the objective function, taking into account geometric constraints by the method of penalty functions, then the complexity increases significantly.

There is "drilling" in one place in the penalty area, which has a complex shape. The exit from the penalty area is very difficult, as a result of which all the considered classical optimization methods do not give the desired result. If we consider only the space of permutations without repetitions, then there is no need for penalty functions. But when using the usual variants of optimization methods, at the very first step, one goes beyond the limits of the considered permissible area. This can be avoided by some modification of the standard optimization methods.

The problem is solved most simply by the coordinate descent method [4]. In this method, steps are taken in turn along each coordinate in order to find the smaller value of the objective function. Here options are possible: you can search for a local minimum for each coordinate with one or another accuracy, for example, you can limit yourself to one step towards decreasing the value of the function, or you can search for the exact value of the coordinate of the local minimum. 
The first approach seems to be pragmatic for a number of reasons, primarily due to the simplification of the algorithm, especially considering the integer nature of the arguments.

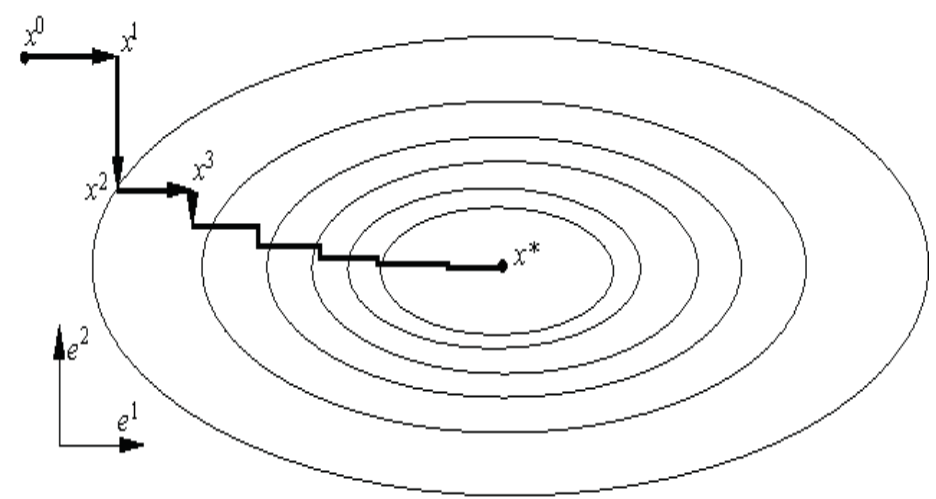

Figure 3. Classical coordinate descent method for two independent variables

At the very first step of the classical optimization procedure for any coordinate, as a rule, an overstepping of the admissible region occurs. In the modified method, after such a step, the permutation is corrected: an argument is found whose value coincides with the new value of the variable coordinate. The value of this argument is replaced with the original value (before the optimization step) of the variable coordinate. As a result, there is a return to the permutation space without repetitions (repetition of position numbers is eliminated). Thus, in the modified method of coordinate descent, at one stage of calculations, two coordinates change simultaneously (and not one, as in the usual optimization method) - one of the coordinates is used for the usual trial step, and for the other, an adjustment is made, returning to the admissible region.

Next, the value of the objective function at the found point is calculated and compared with the previously achieved value. If the value has improved, the found point becomes a new starting point. Otherwise, a step is made along a different coordinate with a simultaneous adjustment of the vector of element position numbers (return to the valid area). It is clear that the considered complication of the coordinate descent method algorithm can lead to some decrease in its usual high efficiency. Nevertheless, the experience of using the modified method in solving the problem of placement of EVA elements has shown its significant advantages over other known methods, for example, the genetic algorithm, as well as the method of penalty functions [1-10].

\section{Calculation example}

The matrix of compounds is given analytically in the form $r_{i j}=i+j(i \neq j), r_{i i}=0,(i, j=1, \ldots, n)$.

Cell step, the number of coordinate steps and the total number of cells and elements: $h=1 ; n_{0}=6 ; n=36$;

First, the search for the initial approximation was carried out by the Monte Carlo method (10,000 iterations), after which the calculations of the local optimum by the modified coordinate descent method in the space of permutations without repetitions were started (a limit of 100 iterations was set). The initial value of the step along the coordinate is $\mathrm{n}$, then at each iteration it decreased by 1 to the minimum possible value equal to 1 . The initial approximation turned out to be $x_{0}=(36,12,6,1,35,19,5,32,31,26,29,34,8,16,28,33,13,24,10,2,18$, 4,27,21,22,15,7,25,11,3,17,9,23,14,20,30),

the penalty function is zero, corresponding to the value of the objective function $f_{\min }=171168.000$.

After calculations by the modified coordinate descent method, the solution has the form:

$x_{1}=(36,1,6,31,35,2,12,32,5,7,25,4,30,33,34,13,19,24,3,18,26,29$, $8,28,11,27,9,10, \quad 23,20,17,14,16,21,15,22)$,

The penalty function is zero, the local optimum is $f_{\min }=$ 171168.000 (the smallest value found for a large number of iterations 171120).

An example of calculations without finding a refined initial approximation. After the first iteration with the Monte Carlo method:

penalty $=0.000, f_{\min 0}=185400.000$;

$x_{0}=(6,30,19,3,12,33,2,10,9,20,18,25,7,26,13,4,24,27,16,23,17$, $8,28,21,5,34,29,11,22,36,15,1,35,31,32,14)$.

The solution found further by the modified coordinate descent method is much better:

penalty $=0.000, f_{\min }=171192.000$;

$x^{(1)}=(6,1,36,31,35,12,5,25,30,2,32,33,7,3,34,18,24,4,19,29,13$,

$8,11,9,26,28,10,20,14,17,27,23,16,15,21,22)$,

\section{Conclusions}

Designed and implemented on a computer modified coordinate descent method for solving the problem of optimal placement of electronic equipment elements. A feature of the method is the absence of a penalty function. The search is automatically carried out in the permutation space without repetitions. Computational experiments have shown high computational qualities of the proposed method.

\section{References}

1. Manual for automatic controlю Edited by A.A. Krasovsky, Moscow: Nauka, 1987, 712 p.

2. G. Korn, T. Korn. Handbook of mathematics. Moscow: Nauka, 1978. $832 \mathrm{p}$.

3. V.A. Trenogin. Functional analysis. Moscow: Nauka. 1980. 496 p.

4. F.P. Vasiliev. Numerical methods for solving extreme problems. Moscow: Nauka, 1988. 552 p.

5. Algorithms for placing elements [Electronic resource]. https://helpiks.org/8-12562.html.

6. N.P. Nikolov. Placement of elements of electronic nodes by multi-level decomposition and macromodeling and implementation on its basis of PPP for CAD REA. Dissertation for the degree of candidate of technical Sciences in the specialty 05.13 .12 "computer-aided design Systems". Lviv, 1985.

7. A.A. Gorbachev. Methods and algorithms for spatial tracing of printed circuit boards. Dissertation for the degree of candidate of technical Sciences in the specialty 05.13.12 "computer-aided design Systems". Kaliningrad, 1999.

8. V.N. Ilyin, V.T. Frolkin, A.I. Butko. Automation of circuit design: Textbook for universities: Moscow: Radio and communications, 1987. 368 p.

9. A.A. Eides. Algorithms for placing elements of radio-electronic equipment that model the tracing process. I telemekh. 1984, no. 12.

P. 145-150.

10. E.N. Merkukhin Optimization of reliability characteristics by rational placement of electronic elements on a Board with heat pipes. Modern problems of science and education. 2015. \# 2-2. URL: http://science-education.ru/ru/article/view?id=22183 (accessed: 17.11.2020) 


\title{
ОПТИМИЗАЦИЯ РАЗМЕЩЕНИЯ РАВНОГАБАРИТНЫХ ЭЛЕМЕНТОВ РЭА МОДИФИЦИРОВАННЫМ МЕТОДОМ ПОКООРДИНАТНОГО СПУСКА
}

\author{
Арутюнян Тигран Робертович, инженер-программист АО "ВПК "НПО машиностроения", Москва, Россия, \\ tigran_201094@mail.ru
}

\section{Аннотация}

Рассматривается задача оптимального размещения элементов электрических и электронных цепей. В качестве критерия выбран минимум взвешенной длины соединений. Предложен вычислительный метод, являющийся модификацией метода покоординатного спуска и одним из вариантов общего подхода на основе парных перестановок. Схема задана матрицей соединений. Рассматривается фиксированный набор позиций элементов и матрица расстояний на основе ортогональной метрики. Данная задача является вариантом общей математической модели, получившей название задачи квадратичного назначения. Геометрическое ограничение задачи - в одной ячейке размещается не более одного элемента. Констатировано, что подходы на основе парных и т.п. перестановок является экономичными, а метод функции штрафа приводит к "забуриванию" и малоэффективен. Описан модифицированный метод покоординатного спуска, являющийся вариантом метода парных перестановок, в котором пары выбираются на основе метода покоординатного спуска. В предложенном варианте метода покоординатного спуска на одном этапе вычислений меняются одновременно две координаты (а не одна, как в обычном методе оптимизации) - по одной из координат делается обычный пробный шаг, а по другой - корректировка, возврат в допустимую область. Далее вычисляется значение целевой функции в найденной точке и сравнивается с достигнутым ранее значением. Если произошло улучшение значения, то найденная точка становится новой стартовой. Иначе делается шаг по другой координате с одновременной корректировкой вектора номеров позиций элементов (возврат в допустимую область). Опыт применения модифицированного метода при решении задачи размещения элементов ЭВА показал его значительные преимущества по сравнению с другими известными методами, например, генетическим алгоритмом, а также методом штрафных функций. Рассмотрен пример вычислений предложенным методом. Матрица соединений была задана аналитически. Вначале осуществлялся поиск начального приближения методом Монте-Карло (10 000 итераций), после чего начинались вычисления локального оптимума модифицированным методом покоординатного спуска в пространстве перестановок без повторений (задавалось ограничение в 100 итераций). Начальное значение шага по координате равно размеру перестановки, далее на каждой итерации оно уменьшалось на I до минимально возможного значения равного І. Преимуществом метода является отсутствие функции штрафа. Поиск автоматически осуществляется в пространстве перестановок без повторений. Вычислительные эксперименты показали высокие вычислительные качества предложенного метода.

Ключевые слова: электрическая схема, ограничения размещения, топологические параметры, метрические параметры, коммутационное поле, критерии и методы оптимизации.

\section{Литература}

І. Справочник по автоматическому управлению/ Под ред. А.А. Красовского. М.: Наука, 1987. 7 І2 с.

2. Корн Г., Корн Т. Справочник по математике. М.: Наука, 1978. 832 с.

3. Треногин В.А. Функциональный анализ. М.: Наука. 1980. 496 с.

4. Васильев Ф.П. Численные методы решения экстремальных задач. М.: Наука, 1988. 552 с.

5. Алгоритмы размещения элементов [Электронный ресурс]. https://helpiks.org/8-I2562.html

6. Николов Н.П. Размещение элементов электронных узлов методом многоуровневой декомпозиции и макромоделирования и реализация на его основе ППП для САПР РЭА. Диссертация на соискание ученой степени кандидата технических наук по специальности 05.І13.12 "Системы автоматизированного проектирования". Львов. 1985.

7. Горбачев А.А. Методы и алгоритмы пространственной трассировки печатных плат. Диссертация на соискание ученой степени кандидата технических наук по специальности 05.13.12 "Системы автоматизированного проектирования". Калининград. 1999.

8. Ильин В.Н., Фролкин В.Т., Бутко А.И. Автоматизация схемотехнического проектирования: Учебное пособие для вузов: М.: Радио и связь, 1987. 368 с.

9. Эйдес А.А. Алгоритмы; размещения элементов радиоэлектронной аппаратуры, моделирующие процесс трассировки // Автомат. и телемех. 1984, № 12. С. 145-150.

I0. Меркухин E.H. Оптимизация характеристик надежности путем рационального размещения электронных элементов на плате с теплопроводами // Современные проблемы науки и образования. 20/5. № 2-2. URL: http://science-education.ru/ru/article/ view?id=22। 83 (дата обращения: I7.1 I.2020). 